\title{
Los orígenes del cómic en la segunda mitad del siglo XIX: de Fliegende Blätter a Little Nemo
}

DR. ROBERTO BARTUAL

\author{
UNIVERSIDAD EUROPEA DE MADRID
}

\begin{abstract}
Después de una breve carrera como actor de cine (El abuelo, la condesa y Escarlata la traviesa, Jess Franco, 1994), Roberto Bartual (Alcobendas, 1976) decidió perseguir la mucho más lucrativa carrera de escritor. Co-autor de La Casa de Bernarda Alba Zombi y traductor, actualmente colabora con el colectivo Dátil (Dramáticas aventuras) y Julián Almazán como guionista en varios proyectos relacionados con el cómic. Sus relatos pueden encontrarse en las antologías Ficciones (Edaf) y Prospectivas (Salto de Página). Es editor y redactor de la sección de cómic de la revista digital Factor Crítico. Obtuvo el premio extraordinario de doctorado 2010/11 en la Universidad Autónoma de Madrid con la tesis Poética de la narración pictográfica: de la tira narrativa al cómic, y su investigación en esta área puede encontrarse en publicaciones como Studies in Comics, Journal of Scandinavian Comic Art o Revista de Arte Goya. Aunque ha descubierto que para ganarse la vida tiene que dar clases de Literatura Infantil y Ciencias Sociales en la Universidad Europea de Madrid.
\end{abstract}

\section{RESUMEN}

Este artículo, en el que se aborda el trabajo de algunos de los pioneros del cómic, tiene una doble intención. En primer lugar, definir la representación secuencial del movimiento como característica básica del cómic y que lo distingue de las narraciones gráficas que le precedieron. En segundo lugar, analizar los parecidos formales entre los cómics de principios de siglo y las primeras películas, con el fin proponer un modelo explicativo diferente al de la influencia mutua; si ambos exhiben recursos narrativos similares es más bien porque se derivan del mismo medio de representación del movimiento: la cronofotografía.

\section{ABSTRACT}

CuCo, Cuadernos de cómic número 1. Septiembre de 2013

CuCoEstudio 
This article deals with the work of some of the pioneers of comics. Its intention is double. In the first place, I try to define sequential representation of movement as one of the basic characteristics of comics; a key formal element that makes the difference between the comics medium and the graphic narratives that preceeded comics. On the other hand, I will analyze the formal coincidences between these turn-of-the-century comics and the first motion pictures with the purpose of debunking the notion that comics were influenced by the formal discoveries of the first movies. I will propose the idea that the reason why they show similar narrative devices is because both comics and movies are derived from chronophotography.

\section{$\underline{\text { Introducción }}$}

Fechar el nacimiento del cómic, identificando el primer título que asume plenamente las características de esta forma narrativa, ha sido una cuestión de especial interés para muchos teóricos del medio. Sin embargo, la principal dificultad a la hora de señalar cuál es el primer cómic es que todavía no hay un consenso generalizado acerca de cuál es la condición sine qua non que define esta forma de narración gráfica.

Algunos estudiosos defienden el uso del término "cómic" para las narraciones gráficas que, haciendo uso de una secuencia de viñetas, las acompañan además de bocadillos. ${ }^{1}$ Entre ellos la respuesta más socorrida al hablar de los orígenes del cómic, suele ser vincularlos a The Yellow Kid; en concreto, a la tira publicada el 25 de octubre de 1896 en el New York Journal. ${ }^{2}$ En dicha tira, el popular "chico de amarillo" mantiene una conversación con un fonógrafo (en cuyo interior se encuentra, en realidad, un loro). Dicha conversación tiene lugar primero a través de los textos impresos en la camiseta amarilla del chico y, finalmente, en la última viñeta, a través de un bocadillo.

Es imposible negar la importancia de esta tira, sobre todo si consideramos que tuvo una enorme influencia en la prensa estadounidense, haciendo que el diálogo

\footnotetext{
${ }^{1}$ Couch, N. C. C. "The Yellow Kid and the comics page", en VARnum, R. y GibBOns, C. T. (eds.). The Language of Comics: Word and Image. Jackson, University Press of Mississippi, 2001, p. 62. GUBERN, R. El lenguaje de los cómics. Barcelona, Península, 1972, p. 15.

${ }^{2}$ GuBERn, R. Op. cit., Barcelona, Península, 1972. p. 21.
} 
articulado mediante bocadillos se generalizase como mecanismo narrativo. El problema es que Richard F. Outcault, el autor de The Yellow Kid, no fue ni mucho menos el primer dibujante que hizo hablar a sus personajes mediante textos impresos sobre sus cabezas. El bocadillo fue un dispositivo formal muy utilizado por los caricaturistas ingleses de la primera mitad del siglo XIX, y en especial por George Cruikshank, quien les dio la forma de nube a lo que hoy estamos acostumbrados. E incluso antes de que se fijara dicha forma de nube, algunos grabadores del XVII como Francis Barlow ya hacían hablar a sus personajes mediante el uso de filacterias, es decir, pergaminos con texto que se desenrollan desde su boca. ${ }^{3}$

Asociar el nacimiento del cómic con el diálogo dramatizado conlleva, asimismo, un segundo problema: ¿qué nos lleva a pensar que el diálogo es el elemento definitorio del cómic? ¿Por qué aplicar al cómic esa vara de medir si no se la aplicamos ni a la novela ni al cine? ¿Acaso el cine mudo no es también cine? ¿Por qué no podemos llamar cómic a las narraciones gráficas sin diálogos o a las que solo incluyen textos en recuadros (FIG. 1)? Esta última posibilidad hace que nos topemos con un nuevo problema. Si aplicamos el término "cómic" a cualquier concatenación secuencial de viñetas, deberíamos fechar su nacimiento en el siglo XV, pues como demostró David Kunzle en su monumental obra The Early Comic Strip: from c. 1450 to 1825 (1973), ya desde la invención de la imprenta se producían tiras con unas características estructurales similares a las de la FIG. 1, salvando las diferencias estilísticas de cada época. ${ }^{4}$

En mi opinión, las dificultades teóricas para fechar el nacimiento del cómic se deben a que sus orígenes no se derivan de la invención de un soporte determinado, como ocurre con el cine. Podemos encontrar narraciones gráficas con viñetas en medios

\footnotetext{
${ }^{3}$ SMOLDEREN, T. "Of Labels, loops and bubbles, solving the historical puzzle of the speech balloon", en Comic Art, n. 8 (2008), pp. 34.

${ }^{4}$ KunZLE, D. The History of the Comic Strip, vol. 1: The Early Comic Strip: Narrative Strips and Picture Stories in the European Broadsheet from c. 1450 to 1825. Berkeley, California, University of California Press, 1973.
}

CuCo, Cuadernos de cómic número 1. Septiembre de 2013 
muy diferentes; incluso antes de la invención de la imprenta, es posible encontrar narraciones secuenciales en los retablos góticos y en las biblias miniadas de la Edad Media. Precisamente algunos investigadores, como Breixo Harguindey, han intentado relacionar los orígenes del cómic con la literatura medieval, ${ }^{5}$ y aunque es cierto que algunas de las narraciones gráficas contenidas en los libros miniados guardan un asombroso parecido con el cómic (FIG. 2), el estatismo que caracteriza este tipo de narraciones nada tiene que ver con la vertiginosa concatenación de imágenes con la que asociamos a la historieta contemporánea.

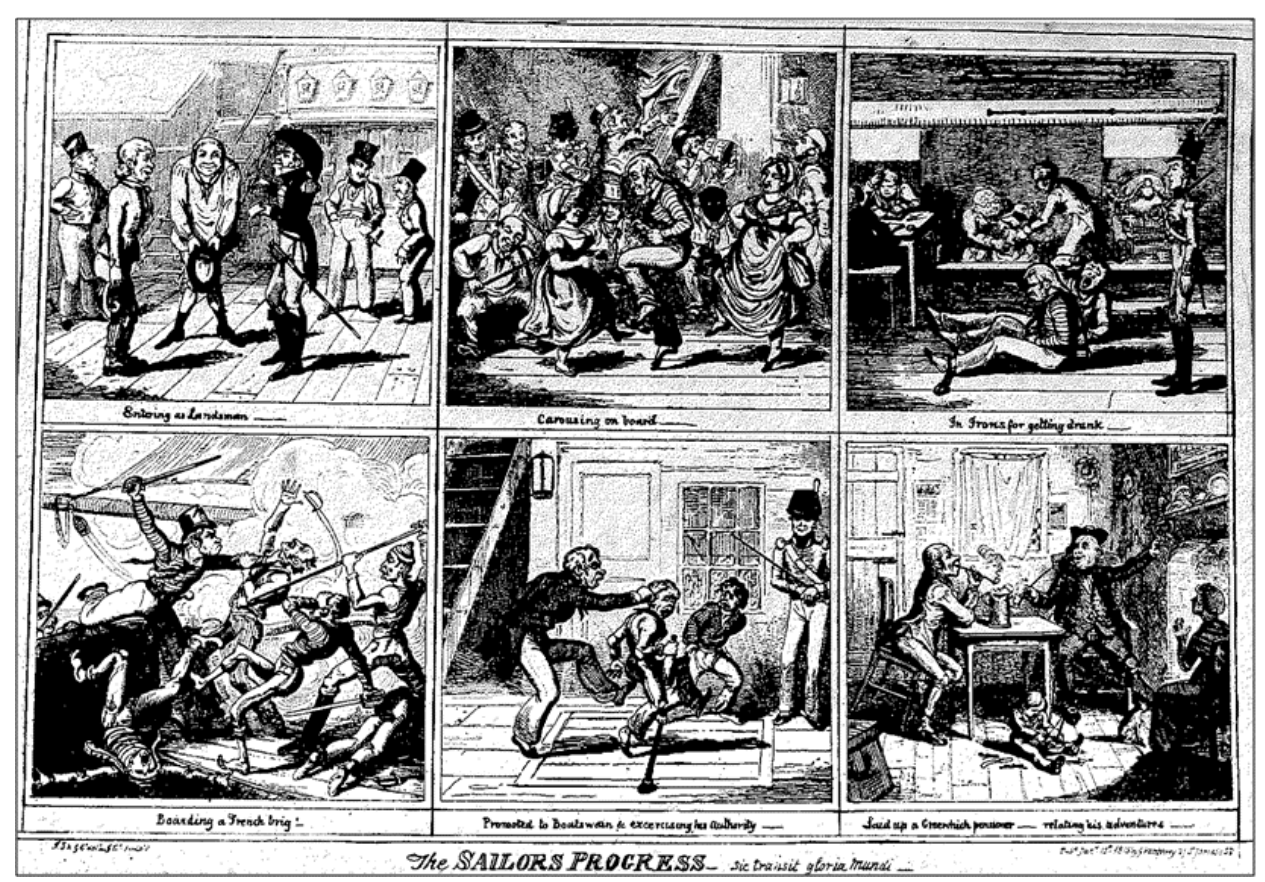

FIG. 1. CRUIKSHANK, G. (1818). The Sailor's Progress.

\footnotetext{
${ }^{5}$ Harguindey, B. “As Cantigas de Santa María: obra mestra das orixes da historieta”, en Boletín galego de literatura, n. 35 (2006), pp. 47-59.
}

CuCo, Cuadernos de cómic número 1. Septiembre de 2013 


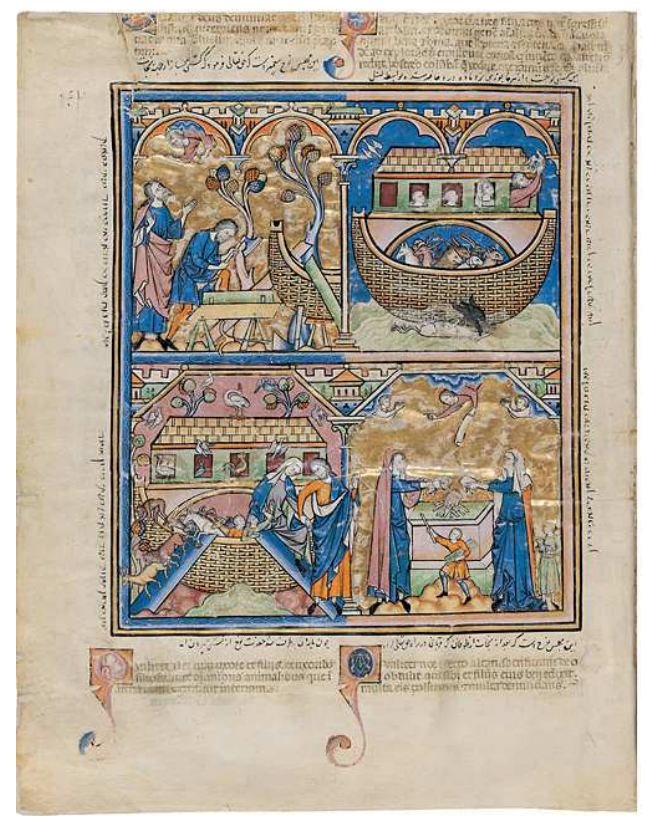

FIG. 2. ANÓNIMO. Biblia Maciejowski, hoja 2, reverso, The Pierpoint Morgan Library, Nueva York, c. 1240.

Hoy en día, páginas como las del Príncipe Valiente de Hal Foster nos resultan relativamente anticuadas pese a su innegable belleza estética, pues la forma en que Foster articula sus imágenes se acerca más al modelo del libro ilustrado que al del cómic contemporáneo. Si observamos con detenimiento una página típica de Foster (FIG. 3), comprobaremos cómo cada una de sus viñetas representa una escena individual; y aunque a lo largo de sus viñetas se repite una misma acción, montar a caballo, la secuencia no produce una verdadera sensación de galope. La estructura episódica de la narración, compuesta por un conjunto de instantes congelados y muy separados temporalmente entre sí, confiere a sus imágenes un estatismo similar al de los manuscritos medievales. 


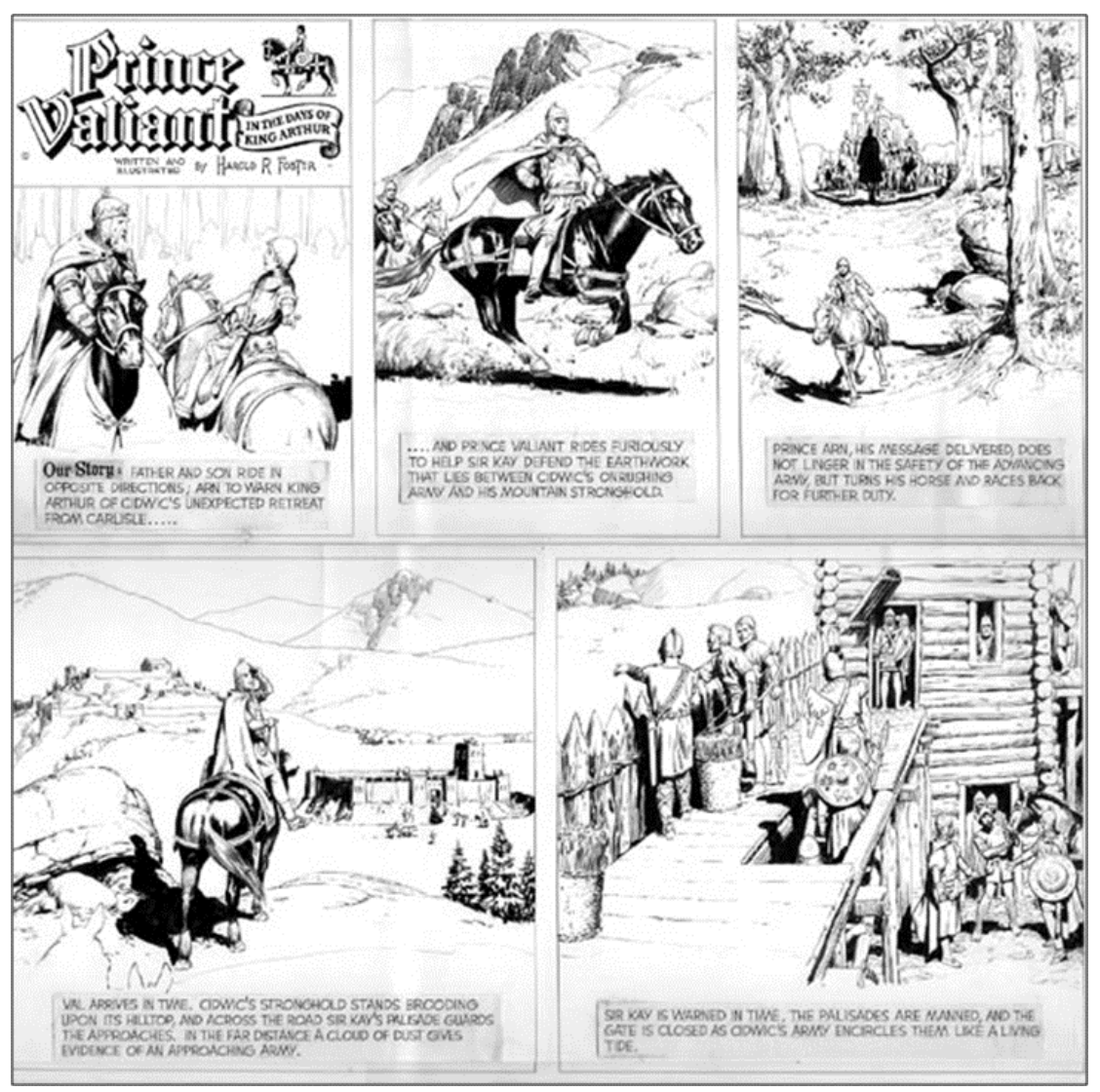

FIG. 3. FOSTER, H. Prince Valiant, 6/3/63.

En cambio, resulta muy revelador comparar este ejemplo con historietas mucho más antiguas que se ajustan bastante mejor a la idea que hemos interiorizado sobre lo que es el cómic. Este el caso de una breve narración de Winsor McCay publicada en Life Magazine sesenta años antes que la anterior página de Hal Foster (FIG. 4). Vemos cómo en ella se mimetiza perfectamente el movimiento de un grupo de indios al galope mediante una técnica similar a la cinematográfica: repitiendo la imagen de los mismos personajes en posiciones sucesivas, lo suficientemente cercanas en el tiempo como para producir una ilusión de movimiento. El dinamismo de los caballos queda reforzado por el hecho de que el punto de vista desde el cual está dibujada la escena cambia de viñeta a viñeta; este es tan móvil como los caballos, ya que durante las cuatro primeras viñetas se desplaza de derecha a izquierda siguiendo lateralmente el avance de los indios hasta la carretera.

CuCo, Cuadernos de cómic número 1. Septiembre de 2013 

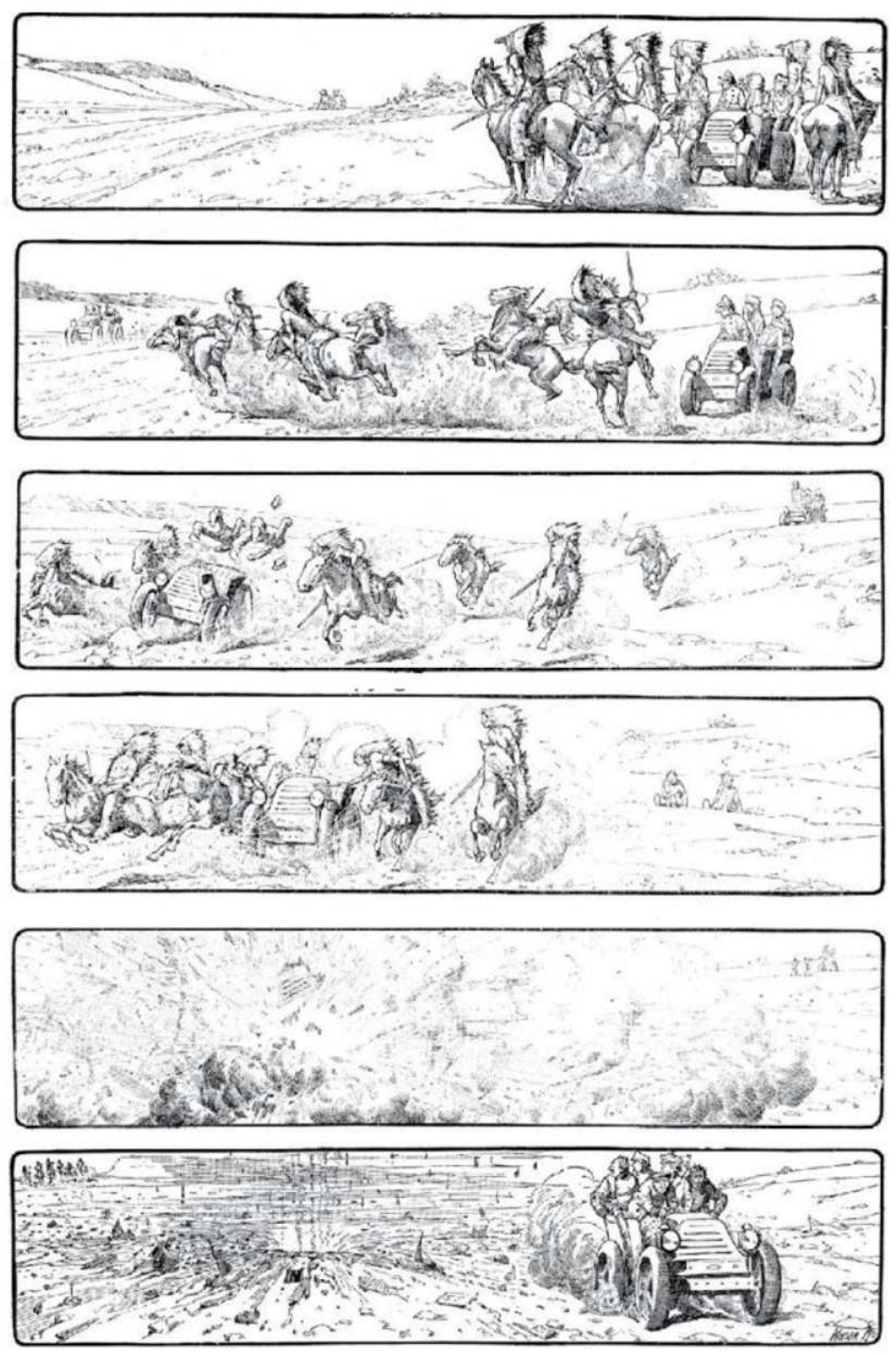

FIG. 4. MCCAY, W. Life Magazine, 1903.

Es indudable la influencia que debió de ejercer en secuencias como esta la entonces reciente invención del cine, pero si prestamos atención a la fecha en fue publicada, descubriremos una interesante paradoja. En ella, McCay usa un encuadre móvil, similar al de una grúa en el cine, para dar más dinamismo al galope de los caballos y acrecentar la sensación de peligro. Es decir, mueve el punto de vista con intenciones puramente narrativas. Sin embargo, en 1903, las grúas no solo eran inexistentes en el cine, sino que además, los tímidos movimientos de cámara que

CuCo, Cuadernos de cómic número 1. Septiembre de 2013 
algunos realizadores incorporaban en sus producciones (básicamente la panorámica y el travelling) apenas eran usados con intenciones narrativas y dramáticas. A pesar de que se habían realizado ya ciertos experimentos con la cámara en movimiento, estos habían sido en su mayor parte fruto del accidente. En 1896, tratando de captar las vistas de un canal veneciano, el operador Promio montó una cámara sobre una góndola, descubriendo al revelar la película, que el escenario y su perspectiva se movían al avanzar la góndola por el canal. ${ }^{6}$ Los movimientos de cámara no pasaron a formar parte del lenguaje narrativo cinematográfico hasta principios de la segunda década del siglo XX, cuando Giovanni Pastrone empezó a usar travellings y panorámicas con intenciones expresivas en su film Cabiria (1914). Y sin embargo, la secuencia de McCay es prueba de que el desplazamiento lateral y en profundidad del punto de vista ya era utilizado en el cómic más de diez años antes de Pastrone con fines deliberadamente narrativos. Más adelante veremos ejemplos incluso anteriores.

Como decía antes, identificar de forma inequívoca el nacimiento del cómic depende en gran medida del modo en que definamos este medio. En este sentido, Scott McCloud ha propuesto una de las definiciones que mayor aceptación académica ha tenido en los últimos veinte años: el cómic es una serie de "imágenes pictóricas (o de otro tipo) yuxtapuestas en secuencia deliberada con el fin de transmitir información y/o producir una respuesta estética en el lector". ${ }^{7}$ Sin embargo, esta definición conlleva ciertos inconvenientes, pues según ella, habría que llamar cómic tanto a la anterior secuencia de McCay a la tira de Cruikshank de la FIG. 1 o a la página de la Biblia Macejoswki reproducida anteriormente. El problema reside en que si observamos detenidamente estos ejemplos comprobaremos que siguen unos principios narrativos totalmente diferentes. Por otro lado, la definición de McCloud sitúa a Winsor McCay al mismo nivel que Hal Foster, sin explicarnos en qué consisten las enormes diferencias

\footnotetext{
${ }^{6}$ MoIX, T. La gran historia del cine. Vol. 1, Madrid, ABC, 1995, p. 75.

${ }^{7}$ MCCLOud, S. Entender el cómic. El arte invisible. Madrid, Astiberri, 1993, 2005, p. 9.
} 
que los separan a nivel formal, ni aclarar por qué nos es más intuitivo asociar a McCay con el cómic actual que a Foster.

Es mi intención proponer aquí un nuevo modo de aproximarnos a los orígenes del cómic, no a través de una fecha preestablecida de forma arbitraria, como hace Gubern, ni mediante una definición amplia y vaga como la de McCloud, sino fijándonos en el elemento que, en mi opinión, marca el inicio del cómic verdaderamente moderno y que separa a este tipo de narración gráfica de aquellas que la precedieron. Dicho elemento es, como pretendo argumentar a continuación, la representación secuencial del movimiento.

\section{Los orígenes de la narración gráfica}

Desde los manuscritos medievales, y durante un periodo muy prolongado de tiempo que finaliza a mediados del siglo XIX, todas las narraciones gráficas con viñetas seguían un procedimiento narrativo muy similar al que Hal Foster utilizó en el Príncipe Valiente. Como en una sucesión estática de tableaux vivants, cada viñeta representaba una sola escena. Las acciones jamás aparecían fraccionadas: en lugar de descomponer en varias imágenes el movimiento inherente a una acción, esta era representada mediante una única imagen especialmente significativa. Cuando el autor quería conferir dinamismo a sus imágenes, empleaba recursos esencialmente pictóricos como la perspectiva o el escorzo. Si Cruikshank nos transmite una fuerte sensación de movimiento en la segunda viñeta de la FIG. 1, es porque para mostrarnos un baile, ha dibujado a algunos personajes con una pierna en el aire mientras la otra permanece en segundo plano parcialmente oscurecida. Cruikshank nunca intentó desarrollar escenas como esta, mostrando los diferentes pasos en que se compone el baile a lo largo de una serie de viñetas.

El primer autor que se atrevió a romper con esta tradición narrativa basada en la progresión estática fue Rodolphe Töpffer. En un pasaje de su primera narración gráfica 
publicada, Monsieur Jabot (1833), su protagonista homónimo se levanta de una silla para bailar y, a continuación, sin cambiar de escena, vemos cómo ejecuta de manera sucesiva algunos de los pasos de su poco ortodoxa danza: primero un paso de cuadrilla; luego, otro de una mazurca (FIG. 5). La sensación de movimiento está todavía poco conseguida, pues la intención de Töpffer no era representar la evolución del baile de manera fluida sino ironizar sobre el hecho de que Jabot está mezclando pasos de diferentes danzas. A pesar de lo cual, Töpffer se atrevió en esta escena a romper la regla de oro a la que se ceñía la narración gráfica hasta entonces: representar en cada viñeta una sola escena.

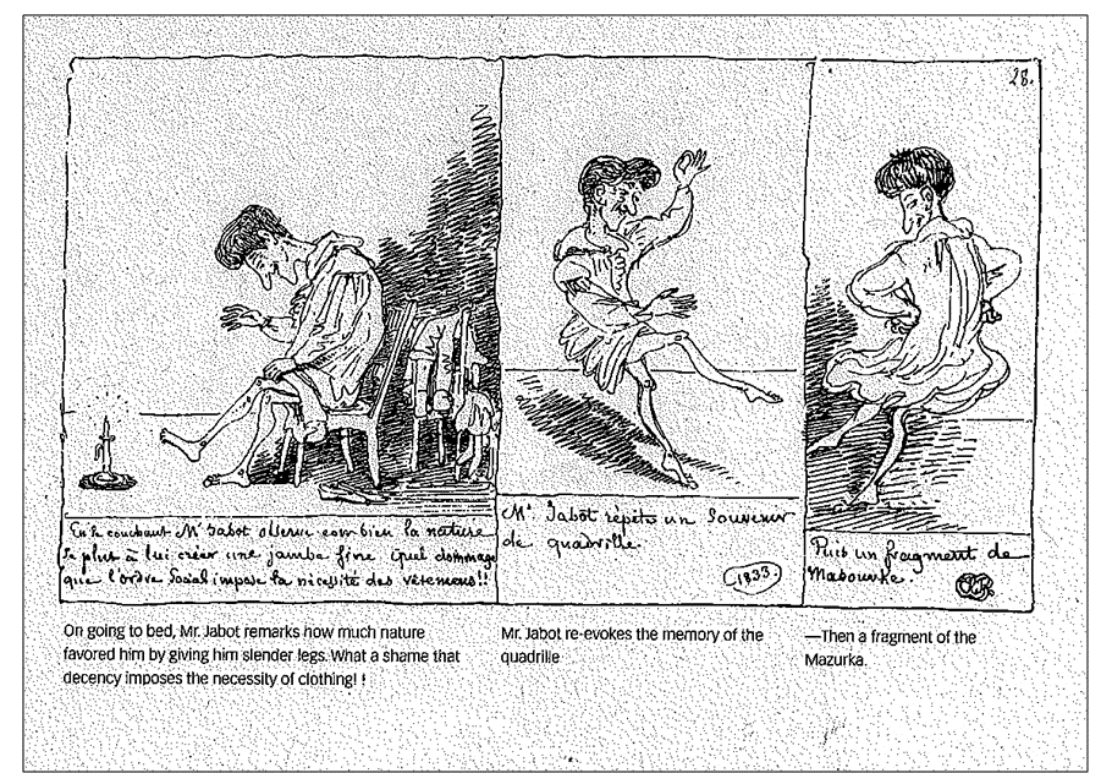

FIG. 5. TÖPFFER, R. Monsieur Jabot. Ginebra. 1833, p. 27.

Llegados a este punto cabe preguntarse por qué desde los inicios de la narración gráfica a mediados del siglo XV y hasta la publicación de los cuentos de Töpffer, casi todos los grabadores se limitaron a plasmar sucesiones de escenas estáticas cerrándose las puertas a la representación secuencial del movimiento. Sabemos que el motivo no puede deberse a una imposibilidad técnica, pues al menos un grabador, Hans Sebald Beham, había producido en 1537 una secuencia (IG. 6) en la que varios campesinos ejecutan los pasos sucesivos de una danza de modo que, a pesar de tratarse de diferentes personajes, es posible reconstruir la evolución del baile como si se tratara de un estudio 
fotográfico del movimiento. Es bastante probable que Beham concibiera estas imágenes para que sus compradores las recortaran, las colocaran en orden cada una debajo de la otra y las pasaran rápidamente con los dedos, obteniendo una lograda sensación óptica de movimiento parecida a la de los primeros zootropos. El posible objeto lúdico de este grabado nada tenía que ver con el del resto de grabados narrativos que se producían en su época, los cuales eran considerados objetos artísticos frecuentemente destinados a su exhibición en las paredes de la casa como un cuadro.

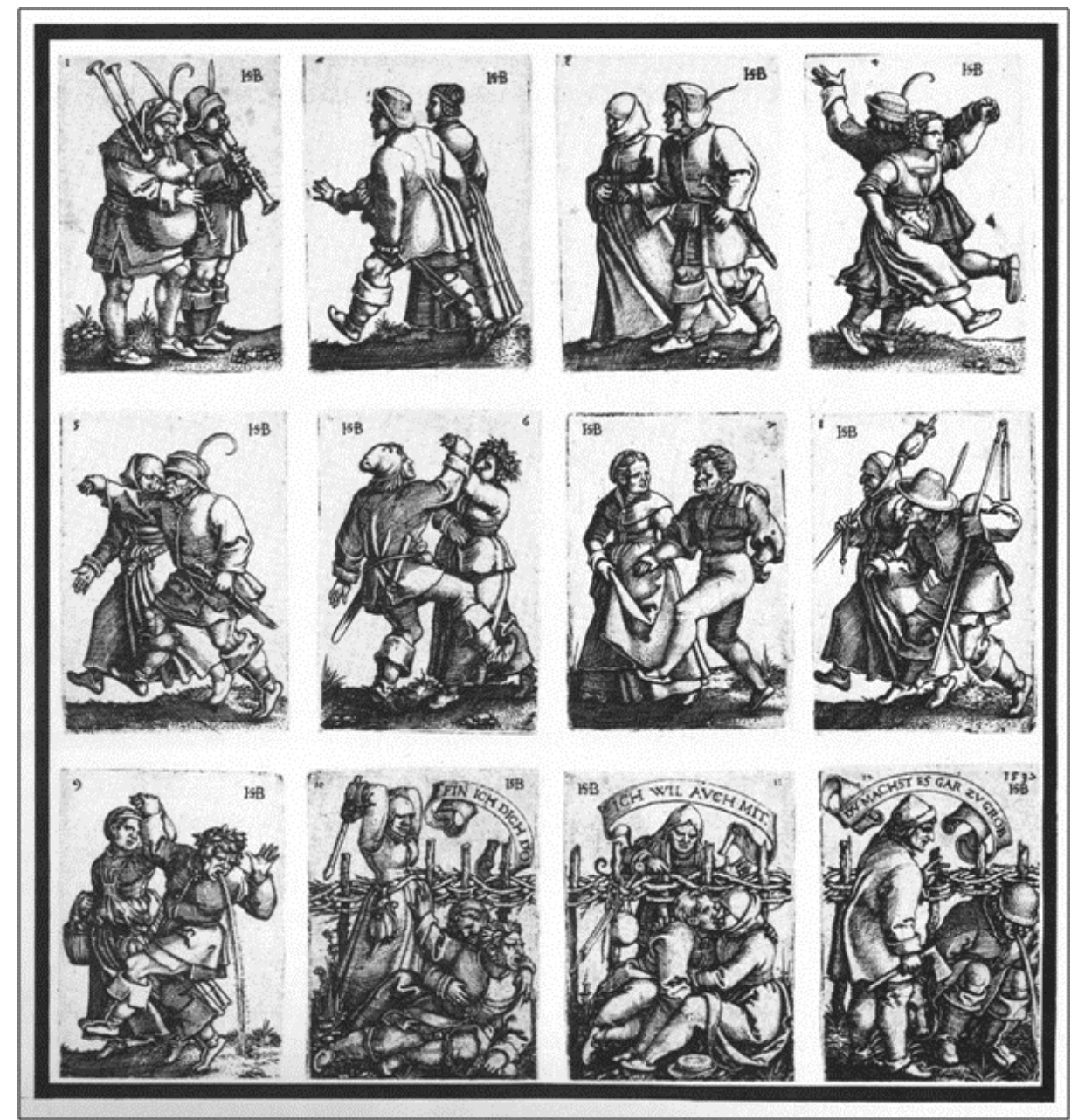

FIG. 6. Sebald Beham, H. (1537). Danza de Campesinos. Madrid, Biblioteca Nacional.

En su obra La novela gráfica, Santiago García glosa una explicación muy convincente, y al mismo tiempo ingeniosa, que da Thierry Smolderen para el extraño hecho de que la representación secuencial del movimiento no volviese a hacer acto de CuCo, Cuadernos de cómic número 1. Septiembre de 2013 
presencia hasta Töpffer, a pesar de que ser bien conocida por los grabadores que le precedieron, como prueban las imágenes de Beham:

\begin{abstract}
El motivo de que la repetición de planos y fondos [con el fin de representar el movimiento] se hubiera evitado en las narraciones con imágenes es muy sencillo: en los grabados tradicionales, el uso de planchas de metal había exigido producir imágenes con una alta densidad de información gráfica que justificara su alto precio. Uno no compraba una estampa con seis imágenes para que las seis imágenes solo ofrecieran variaciones paso a paso en el movimiento de los personajes principales: la rentabilidad estaba en poder disfrutar de seis escenas diferentes - aunque relacionadas-, que se pudieran contemplar con deleite estético, y no tanto leerlas rápidamente, como es inevitable hacer con los libros de Töpffer. ${ }^{8}$
\end{abstract}

Si Töpffer pudo romper con esta tendencia a producir imágenes disímiles pero estáticas, se debe a que el formato que eligió para plasmar sus narraciones gráficas no fue la estampa o la hoja volandera, sino el libro, algo insólito hasta entonces. Durante la década de 1830, Rodolphe Töpffer era conocido en Ginebra por ser

el director de un célebre internado para niños de la zona (...) y por ser el autor de una serie de álbumes manuscritos con cuentos en imágenes que eran devorados ávidamente por los niños de su escuela y por su círculo de amigos. ${ }^{9}$

Estos libros apaisados, impresos y encuadernados artesanalmente, fueron presentados a Goethe por un amigo común, y enseguida contaron con la aprobación del escritor alemán, quien animó a Töpffer para que los publicara con el mismo formato en el que habían sido concebidos.

El formato libro afectó de manera decisiva a la estructura de sus narraciones gráficas. Hasta entonces los narradores gráficos habían contado con un número muy limitado de viñetas para contar sus historias, pues estas eran impresas en páginas

8 GARcíA, S. La novela gráfica. Madrid, Astiberri, 2010, pp. 55-56. SMOLDEREN, T. “A. B. Frost et la révolution photographique", en Naissances de la Bande Desinée. Bruselas, Les Impressions Nouvelles, 2009. SMOLDEREN, T. "A. B. Frost: First Stories and the Photographic Revolution", en www.nwe.ulf.edu/ ronan/ThierryS.html, ultimo acceso 10/3/2002.

9 Kunzle, D. The History of the Comic Strip, vol. 2: The Nineteenth Century. Berkeley, California, University of California Press, 1990.

CuCo, Cuadernos de cómic número 1. Septiembre de 2013

CuCoEstudio 
individuales; sin embargo, al utilizar el libro como soporte, Töpffer dejó de verse constreñido por las dimensiones de la página: sus historias podían tener la extensión que quisiera. Si, por su forzosa brevedad, las narraciones contenidas en las tiras anteriores a Töpffer tenían por lo general un carácter anecdótico, o cuando eran cómicas, no pasaban de ser un chiste, los "cuentos en imágenes" de Töpffer se acercaban más a la estructura de una novela.

Pero esta no fue la única consecuencia derivada del formato: al contar con un espacio tan extenso, Töpffer dejó de verse limitado a plasmar sucesiones estáticas de escenas. Ya no era necesario economizar los espacios en blanco dibujando solo una viñeta por escena; muy al contrario, Töpffer solía dedicar páginas enteras a cada escena (y en ocasiones, varias páginas), fragmentando una sola acción o un solo evento narrativo y representándolo mediante un conjunto de imágenes. Siguiendo el razonamiento de Santiago García, Töpffer pudo introducir la representación secuencial del movimiento (si bien tosca) en la narración gráfica porque, al utilizar el libro como soporte, destinándolo a la lectura privada y no a la exhibición pública, ningún comprador podría quejarse de su elevada tendencia a repetir dibujos similares.

Con Töpffer, la narración gráfica dejó de ser un objeto destinado a la mera contemplación para convertirse en un género literario en el que el movimiento en sí mismo deviene en uno de sus principales temas. En los “cuentos en imágenes" de Töpffer, como él mismo los llamaba, ${ }^{10}$ podemos encontrar locas persecuciones a la carrera, a caballo o incluso en bote (Les Amours de M. Vieux Bois, 1835), viajes aéreos gracias al impulso del céfiro (M. Pencil, 1840), la aparatosa caída de veinticinco hombres subidos a una escalera (Le Docteur Festus, 1840) y un largo sinfín de gags físicos, anticipando así un género de comedia, el slapstick o "comedia física" que tres

10 TÖpfFer, R. "Essay de Physiognomonie", en Groensteen, T. y PeEters, B. (eds.). Töpffer. L'invention de la bande dessinée. París, Hermann, 1875, 1994, pp. 201. 
cuartos de siglo después triunfaría en el cine de la mano de Fatty Arbuckle, Charlie Chaplin o Stan Laurel y Oliver Hardy.

\section{Los seguidores de Töpffer}

El modelo de narración gráfica ideado por Töpffer tendría continuidad, desde mediados del siglo XIX, en un formato muy distinto: las tiras breves publicadas en revistas satíricas. Publicaciones como Punch, en Londres, Fliegende Blätter en Munich, L'Illustration o el Journal por Rire de París, dieron prioridad en sus páginas a secuencias cómicas de humor físico como las de Töpffer, compuestas en muchas ocasiones por una sola secuencia fragmentada en varias viñetas. La técnica de estas secuencias es similar a la de Töpffer; en ellas la sensación de movimiento es todavía torpe pues los dibujantes se limitan a presentar a los mismos personajes adoptando posturas diferentes (FIG. 7). 


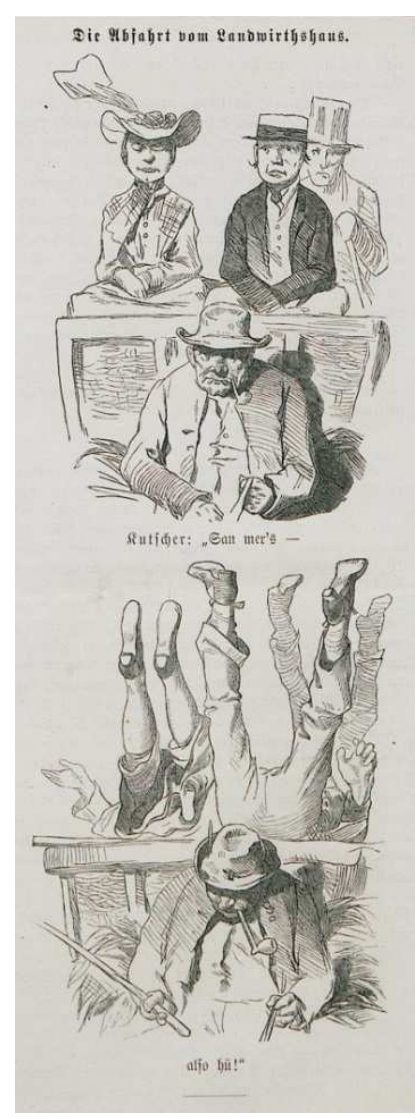

FIG. 7. ANÓNIMO; Fliegende Blätter, $n^{o}$ 1572, Heidelberg,

Universitätsbibliothek, 1875 , p. 4.

Thierry Smolderen relaciona esta tendencia con la influencia que tuvo en Europa la publicación del Laocoonte (1776) de Lessing, ensayo en el que el filósofo y dramaturgo alemán reflexiona sobre la idea de acción como núcleo de la actividad poética. Según Smolderen:

[Lessing] deja entrever la posibilidad de crear sistemas gráficos capaces de fijar, con fines didácticos, las fases de una acción progresiva. Después del Laocoonte, las obras ilustradas destinadas a actores y oradores irán mostrando un interés creciente por esta cuestión. ${ }^{11}$

Una de estas obras es Practical Illustrations of Rethorical Gestures and Action, un trabajo de Henry Siddons basado en un ensayo de Johann Jakob Engel, en el que se

\footnotetext{
${ }^{11}$ SMOLDEREN, T. Naissances de la bande dessinée. Bruselas, Les Impresions Nouvelles, 2009, p. 43.
} 
descompone el sistema gestual del melodrama, ilustrándolo con diversas posturas estereotipadas. En él se inspiró Töpffer para parodiar este género (otro de sus temas recurrentes) en las páginas de Mr. Vieux Bois (1839), obteniendo secuencias como la que encontramos en la franja inferior de la FIG. 8, donde la fragmentación de la escena responde no tanto a un deseo de representar el movimiento, como de burlarse de las diferentes fases por las que pasa el enamorado al ver cómo se aleja su amada: devoción, decepción y sospecha.
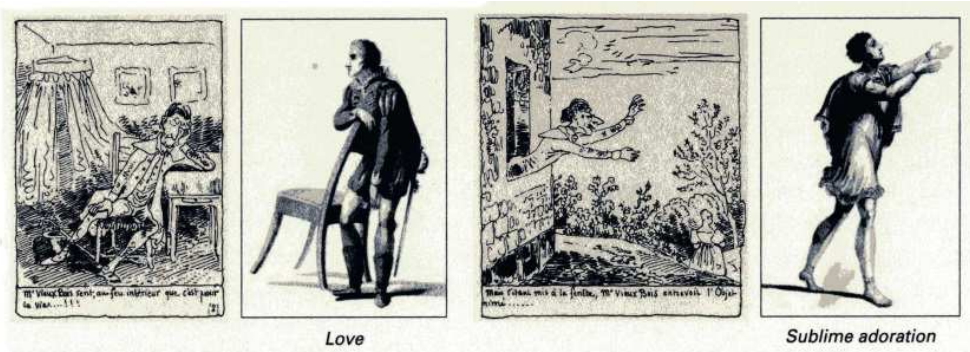

Sublime adoration
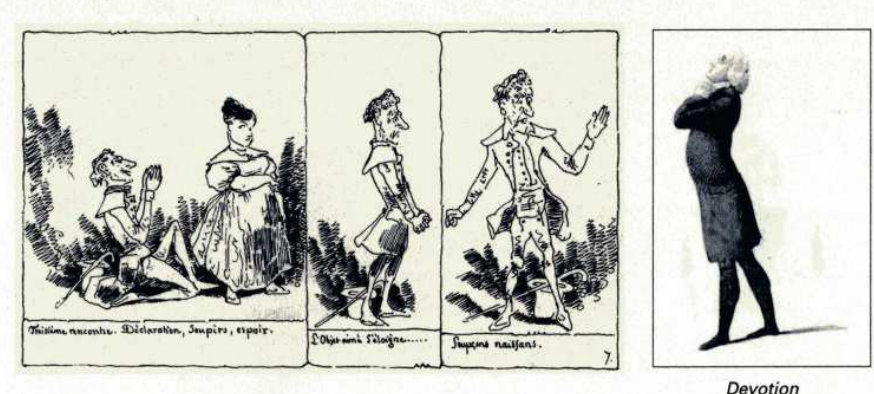

Devotion
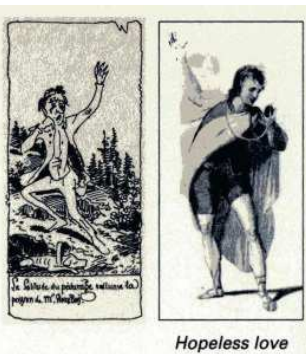

Hopeless love
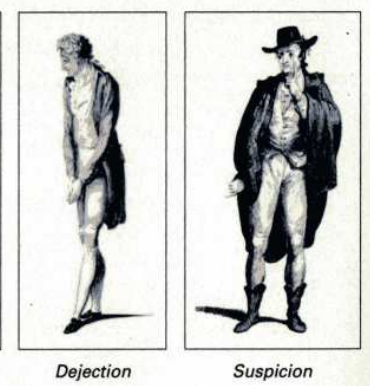

FIG. 8. TÖPFFER, R. Les Amours de Mr. Vieux Bois, Ginebra, 1839; SIDDONS, H. Practical Illustrations of Rhetorical Gestures and Action, from a work on the subject by J. J. Engel, Londres, 1822. Imagen reproducida en SMOLDEREN, T. Naissances de la Bande Dessinée, Bruselas, Les Impresions Nouvelles, 2009.

Este mismo sentido, según Smolderen, es el que debemos dar a secuencias como la anterior de la revista Fliegende Blätter (FIG. 7) donde la adopción del gestual e irónico "lenguaje de Töpffer se convierte en una forma de traducción complaciente (y sonriente) de los comportamientos estereotipados con los que, alrededor de 1850, los lectores de las revistas satíricas se podían identificar". ${ }^{12}$ Aunque la misma acción, la

\footnotetext{
${ }^{12}$ SMOLDEREN, T. Op. Cit., p. 82.
} 
puesta en marcha de una calesa, es segmentada en momentos diferentes, en esta secuencia no interesa tanto la representación de un movimiento, como el contraste cómico entre los instantes representados. Igual que Töpffer, lo que interesa es el paso de un sentimiento a otro, de una postura a la siguiente, y no la transición fluida entre ambos momentos, ya que la comicidad de la escena reside en el salto brusco de la dignidad con que la familia se dispone a emprender el viaje a su casa de campo, con el ridículo que hacen al caer cuando el cochero exclama un súbito “¡arre!”.

El contraste entre posturas y expresiones estereotipadas, sobre todo si el paso de una a otra es fulminante, fue en un primer momento, el principal motor cómico de las secuencias gráficas publicadas en las revistas satíricas europeas durante buena parte del siglo XIX. Un examen pormenorizado del archivo de una de las revistas más importantes de esa época, Fliegende Blätter, ${ }^{13}$ demuestra que solo después de 1878 empiezan a aparecer secuencias cuya constante es una representación secuencial fluida del movimiento (FIG. 9). La respuesta a por qué se produce dicho punto de inflexión en una fecha tan concreta es sencilla.

En 1878 Eadweard Muybridge publicó su primer estudio cronofotográfico, The Horse in Motion, por iniciativa del exgobernador de California Leland Stanford (FIG. 10). Aficionado a las carreras de caballos, Stanford había apostado una fuerte suma de dinero contra unos amigos aficionados también a la hípica, pues tenía la sospecha de que los caballos, al trotar, llegaban a tener en algún momento las cuatro pezuñas en el aire al mismo tiempo. Sus amigos se negaban a creerlo, por lo que Stanford encargó a Muybridge que ideara un sistema para probarlo, creando una cámara lo suficientemente rápida como para capturar el galope de un caballo con un intervalo mínimo de tiempo entre disparo y disparo. ${ }^{14}$ El resultado, publicado en The Horse in Motion, probó la

\footnotetext{
${ }^{13}$ La Ruprecht-Karls-Universität de Heidelberg alberga el archivo digital de dicha revista, que comprende todos los números publicados desde 1845 hasta 1944. Está disponible on line en: http://diglit.ub.uniheidelberg.de/diglit/fb

${ }^{14}$ Williams, A. L. Republic of Images: A History of French Filmmaking. Harvard University Press, 1992, p. 17.
} 
teoría de Stanford, convirtiéndose a su vez en la primera filmación de un ser vivo en movimiento.

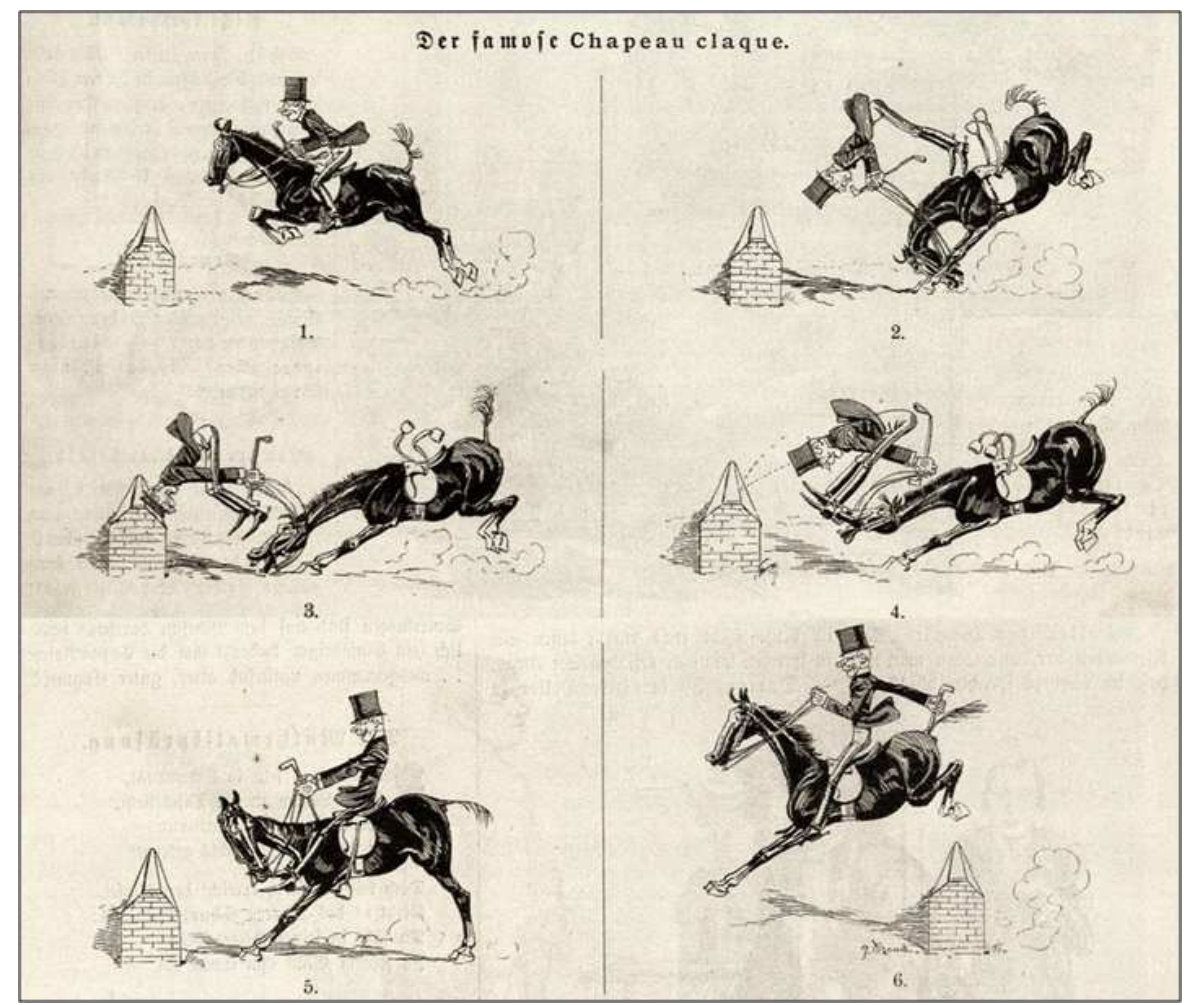

FIG. 9. ANÓNIMO. Fliegende Blätter, n. ${ }^{\circ}$ 2458, Heidelberg, Universitätsbibliothek, 1892, pp. 88 y 89.

En los años que siguieron, Muybridge fue haciendo públicos sus estudios cronofotográficos sobre el movimiento animal y humano, y mientras tanto, narradores gráficos de toda Europa y Estados Unidos empezaban a utilizar sus fotografías como referencia para sus personajes (FIG. 11 y $\underline{12}$ ). De este modo, el cómic pudo adquirir un dinamismo inusitado, convirtiéndose plenamente en lo que ya es hoy: no solo un mecanismo de narración con imágenes, sino también un modo de representación mimética de la realidad mediante el cual fue posible representar el movimiento humano y animal de forma muy precisa, del mismo modo en que durante esos mismos años empezaría a hacerlo el cinematógrafo. La tira cómica había pasado de ser un sistema esencialmente narrativo a convertirse en un sistema mostrativo, por utilizar la 
terminología establecida por Gaudreault y Jost; ${ }^{15}$ es decir, un medio fundamentalmente dramático que, en lugar de narrar la acción, la muestra de manera detallada.

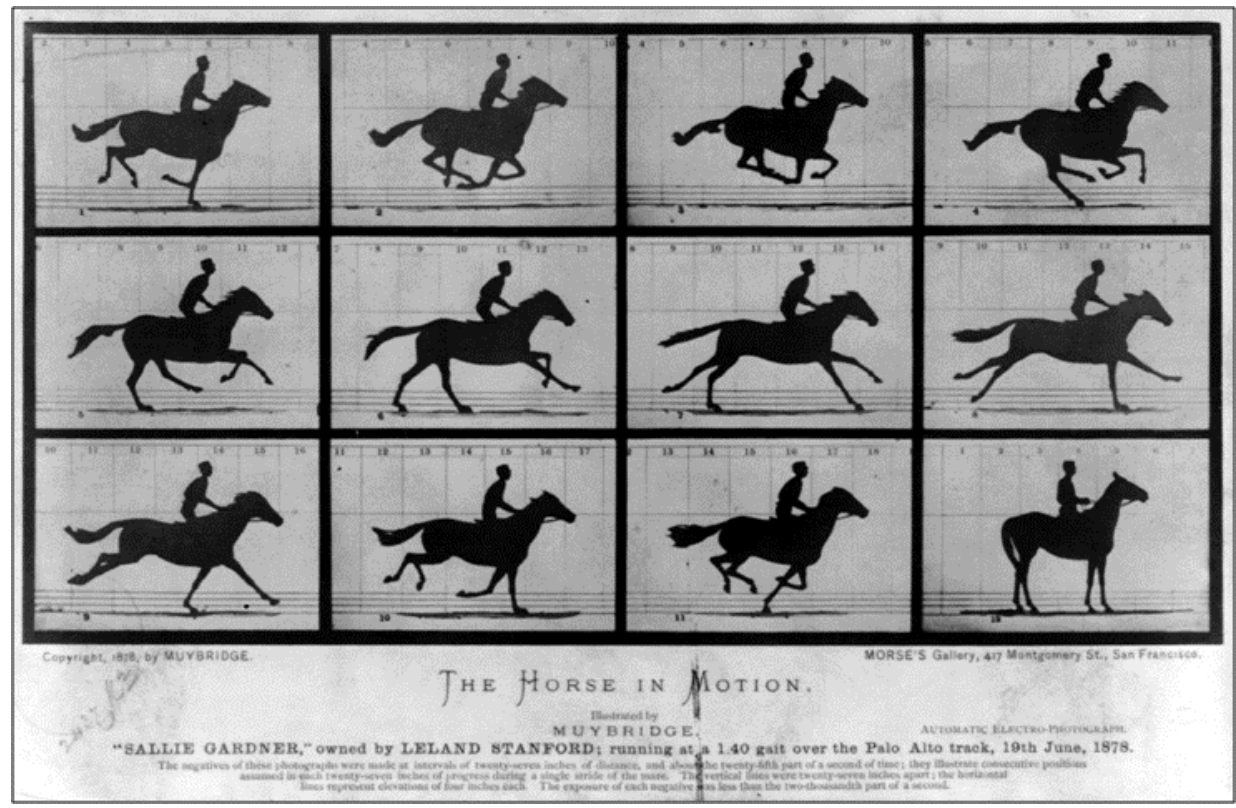

FIG. 10. MuYBridge, E. The Horse in Motion. Philadelphia, University of Pennsylvania Archives \& Record Center, 1878.
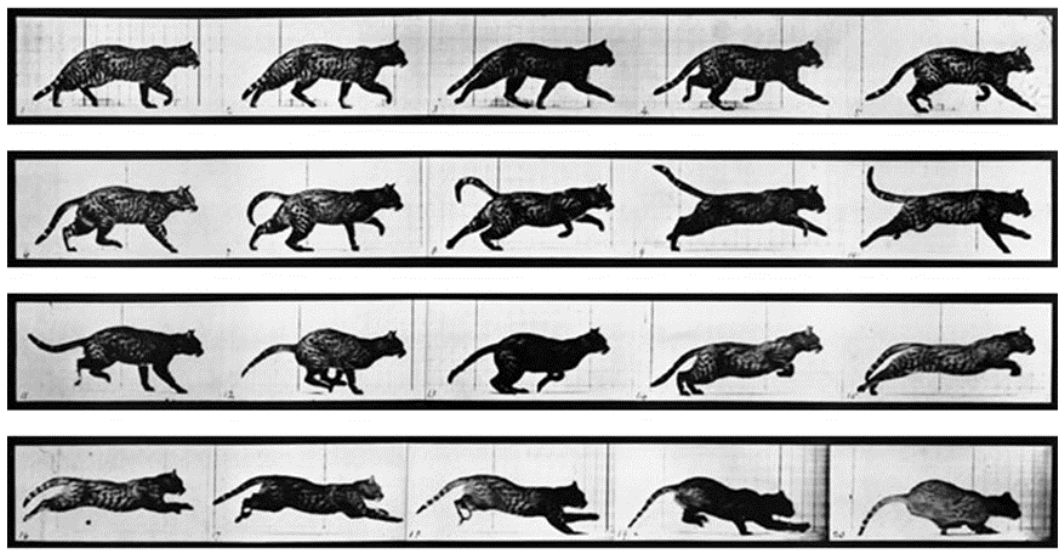

FIG. 11. MuYBrIDGE, E. Animal Locomotion. Philadelphia, University of Pennsylvania Archives \& Record Center, 1887.

${ }^{15}$ Gaudreault, A. y Jost, F. El relato cinematográfico. Barcelona, Paidos, 1995, p. 33.

CuCo, Cuadernos de cómic número 1. Septiembre de 2013 


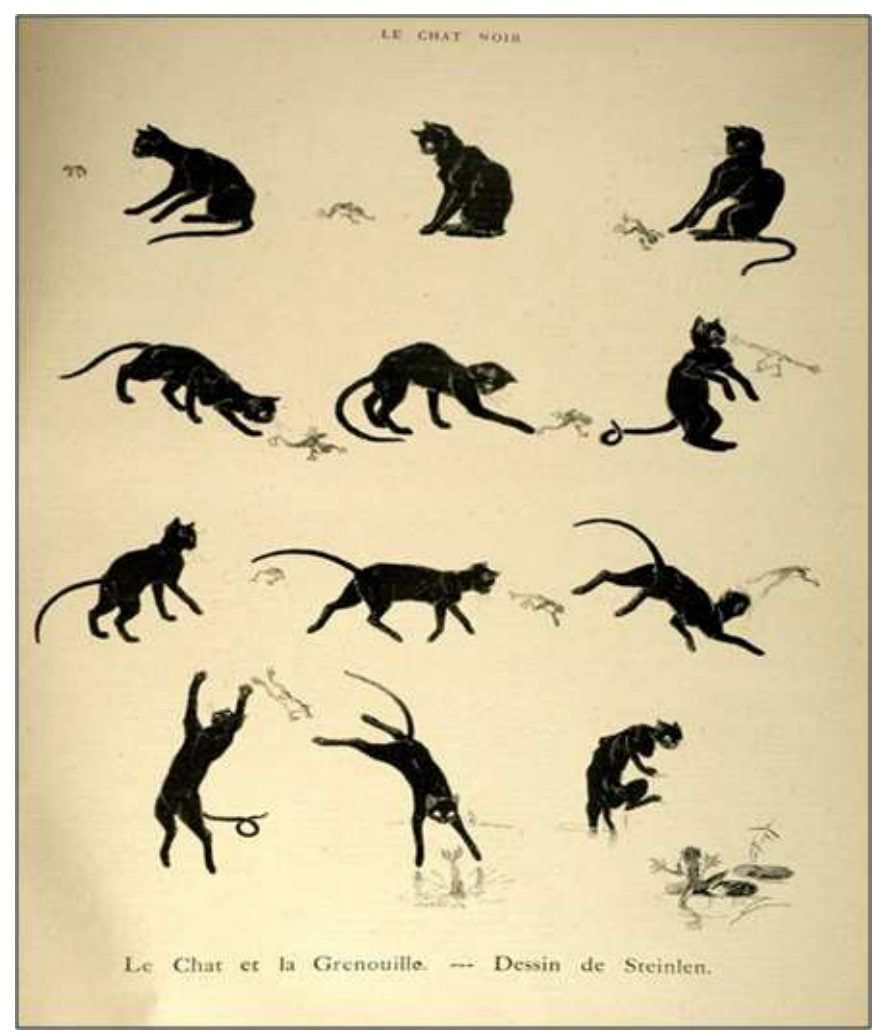

FIG. 12. SteInLEN, T-A. "Le Chat et la Grenouille", en Chat Noir, n. ${ }^{\circ}$ 141, 20/9/1884.

\section{$\underline{\text { El cómic y el cine en sus inicios }}$}

Mucho se ha hablado de la influencia del cine en los primeros cómics publicados durante la última década del siglo XIX y la primera del XX. ${ }^{16} \mathrm{Y}$ sin embargo, como ya he avanzado al comienzo de este texto, existen ciertas secuencias gráficas que ponen en entredicho tal influencia, o que al menos desmienten que dicha influencia se produjera en una sola dirección (FIG. 4). Al menos, así nos lo demuestra la aparición de determinados recursos cinematográficos en la obra de Winsor McCay y en las páginas de Fliegende Blätter, antes de que dichos recursos hicieran acto de presencia en el cine.

${ }^{16}$ RICKMAN, L. "Bande dessinée and the cinematograph: visual narrative in 1895”, en European Comic Art. Vol. 1, n. ${ }^{\circ} 1$ (2008), pp. 1-19.

CuCo, Cuadernos de cómic número 1. Septiembre de 2013 
El punto de vista móvil, por ejemplo, hace acto de presencia en el cómic mucho antes que en el cine. Ya en una secuencia de Alfred Öberlander publicada en Fliegende Blätter en 1889, vemos cómo el encuadre se desplaza en círculos girando en torno a un bebé que juega con un perro, bastantes décadas antes de que en el cine comenzaran a utilizarse raíles para dar a la cámara la posibilidad de moverse de forma similar. ${ }^{17}$ Unos años más tarde, en 1892, una tira de Emil Reinicke nos muestra a un hombre cayéndose del último vagón de un tren mientras el punto de vista se aleja de él, fijo en la plataforma del tren que sigue su marcha. ${ }^{18}$

¿Cómo es posible que el primer movimiento rotatorio de cámara y el primer travelling inverso nacieran, no en el cine, sino en las páginas de una revista satírica? (Recordemos que el primer travelling cinematográfico data de 1896). La respuesta la encontramos de nuevo en Muybridge. En 1887 empezaron a hacerse públicas en revistas de todo el mundo las 781 planchas fotográficas que, bajo el título genérico de Animal Locomotion, comprendían todos los estudios cronofotográficos que había realizado hasta la fecha. Algunas debieron servir de referencia a artistas como Öberlander y Reinicke, pues se observan en ellas movimientos similares a los que estos reproducen en sus secuencias gráficas. En la plancha número 48 de Animal Locomotion se observa cómo una mujer gira sobre su propio eje lentamente, ofreciendo una vista clara de todas sus posiciones; ${ }^{19}$ las mismas que registraría una cámara que girase en torno a un personaje estático como el bebé de Öberlander. Otras muchas planchas de la serie de Muybridge muestran cómo la cámara se mueve en profundidad siguiendo a un animal

\footnotetext{
${ }^{17}$ En Fliegende Blätter, n. ${ }^{o}$ 2304, Heidelberg, Ruprecht-Karls-Universität, 1889 (n. $\left.{ }^{\text {os }} 2293-2318\right)$, p. 105.

${ }^{18}$ En Fliegende Blätter, n. ${ }^{\text {2 } 449, ~ H e i d e l b e r g, ~ R u p r e c h t-K a r l s-U n i v e r s i t a ̈ t, ~ p p . ~} 11$ y 12.

${ }^{19}$ El University Archives \& Records Center de la Universidad de Pennsylvania alberga 702 de las 781 planchas que componen la colección Animal Locomotion. Aproximadamente 100 de ellas están disponibles para su consulta on line en:
}

http://www.archives.upenn.edu/primdocs/upt/upt50/upt50m993/upt50m993.html 
que se aleja o se acerca al fotógrafo, ${ }^{20}$ al mismo tiempo que el fondo se acerca o se aleja respectivamente, como ocurría en la secuencia de Reinicke.

La forma que tenemos actualmente de concebir el movimiento de los animales, del cuerpo humano y también la manera en que el mundo cambia desde nuestro punto de vista al movernos, se deriva de la cámara móvil de Muybridge. La evolución por fases de dicho movimiento sería codificada años después por el cine y el cómic de manera casi simultánea. Sin embargo, si estudiamos detenidamente las páginas de uno de los títulos pioneros del cómic, Little Nemo, podremos comprobar cómo fue en las páginas de los diarios estadounidenses y no en las pantallas de los Nickelodeones, donde empezaron a estandarizarse y a fijarse los principales movimientos de "cámara" que solo años más tarde pasarían a formar parte del lenguaje cinematográfico.

\section{McCay y el mundo móvil}

La influencia de Muybridge en el Little Nemo de Winsor McCay parece fuera de toda duda, tal y como argumenta Jeet Heer en un breve ensayo publicado en Comics Comics Magazine. ${ }^{21}$ Heer encuentra evidencia clara de esta influencia en la famosa escena de la cama galopante (26 de julio de 1908), cuyas patas reproducen el movimiento de las de un caballo tal y como fueron fotografiadas por Muybridge. Sin embargo, ya es posible encontrar la misma evidencia en otra página de Little Nemo publicada años antes. Se trata, de hecho, de su página inaugural. En ella, Nemo es conducido al país de los sueños a lomos de un caballo y en una de las viñetas, McCay dibuja a su montura con las pezuñas recogidas y en aire, sin tocar el suelo (FIG. 13), es decir: precisamente la misma postura que Muybridge había tratado de demostrar con su experimento

\footnotetext{
${ }^{20}$ Por ejemplo, la plancha que lleva el número 686.

${ }^{21}$ HeER, J. “Comics and Photography: Research Note 1", en Comics Comics Magazine (2010), disponible on line en: http://comicscomicsmag.com/2010/02/comics-and-photography-research-note-1.html
} 
cronofotográfico. No existen pruebas de que McCay copiase directamente las fotografías de Muybridge, pero estos y muchos otros ejemplos más de movimiento animal en las páginas de Little Nemo, demuestran que McCay debió haber visto y estudiado en profundidad las imágenes de Muybridge, pues Animal Locomotion contiene estudios de todos los animales en movimiento representados por McCay; incluyendo camellos (página del 25 de marzo de 1906) y leones (28 de enero de 1906).

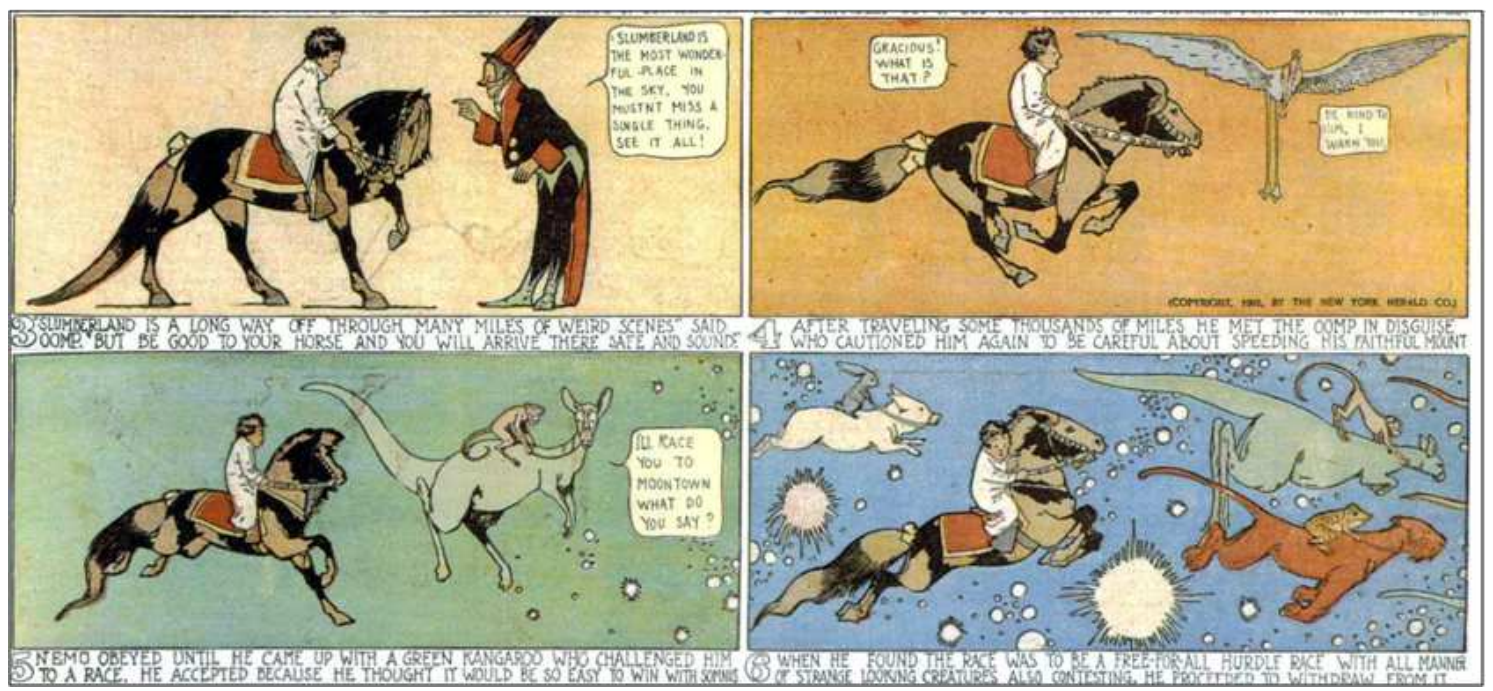

FIG. 13. MCCAY, W. Little Nemo, en The New York Herald, 15/10/1905.

No era el primer dibujante que adaptaba al cómic los hallazgos de Muybridge. Otros como Öberlander, Reinicke o Steinlein le precedieron, como hemos visto antes; y en los Estados Unidos, durante la década de los ochenta, A. B. Frost ya se había hecho popular por sus vivísimas secuencias en movimiento que constituían en cierto modo divertidas parodias de las de Muybridge. ${ }^{22}$ Por ejemplo, en una tira representa en seis viñetas los movimientos de la boca de un hombre mientras pronuncia en sonido "th" (Harper's New Monthly, diciembre 1879), y en otra los movimientos de un hombre que se comporta como una cabra (The Ladies Home Journal, 1915), llevando al absurdo el interés científico por los continuos cambios de posición del ser humano. Pero aunque otros autores habían sacado partido de los hallazgos de Muybridge antes que McCay (e

${ }^{22}$ SMOLDEREN, T. Op. cit., pp. 103-117.

CuCo, Cuadernos de cómic número 1. Septiembre de 2013

CuCoEstudio 
incluso algunos, como A. B. Frost, con mayor precisión que él), el creador de Little Nemo fue el primer artista que incorporó al lenguaje del cómic un aspecto mucho menos visible de las fotografías de Muybridge sobre el que apenas se había discutido hasta entonces: los movimientos de cámara.

Si observamos con detenimiento algunas de las secuencias de Muybridge, en concreto, aquellas que implican desplazamientos laterales (FIG. 10) o en profundidad (FIG. 14), veremos cómo los fondos aparecen también sutilmente desplazados, pues evidentemente, Muybridge tuvo que mover la cámara en la misma dirección y sentido que el sujeto móvil para poder registrar sus cambios de postura sin salir del encuadre. Sin embargo, lo que para Muybridge era una simple necesidad práctica, McCay lo convirtió en el verdadero motor de sus viñetas: la posibilidad de mover el mundo mediante la secuenciación de la mirada. El protagonista de la página del 3 de enero de 1909 es un tren que avanza hacia el lector mientras el punto de vista se mantiene fijo sobre la locomotora, y por lo tanto, alejándose paulatinamente del paisaje que esta deja tras de sí (FIG. 15). Se trata de un travelling inverso como el de la tira de Reinicke mencionada anteriormente, y sin embargo aquí ya no se trata de un experimento puntual sin solución de continuidad: por un lado, lo llegó a utilizar en muchas otras ocasiones convirtiéndolo en un recurso estándar del lenguaje del cómic; por otro, le dio siempre una intencionalidad retórica, es decir, el propósito de desplazar en profundidad el encuadre de la viñeta tenía siempre como propósito reforzar la violenta sensación de movimiento del medio de transporte en cuestión, ya fuera una barca (página del 28 de abril de 1907) o un coche (17 de agosto de 1924).

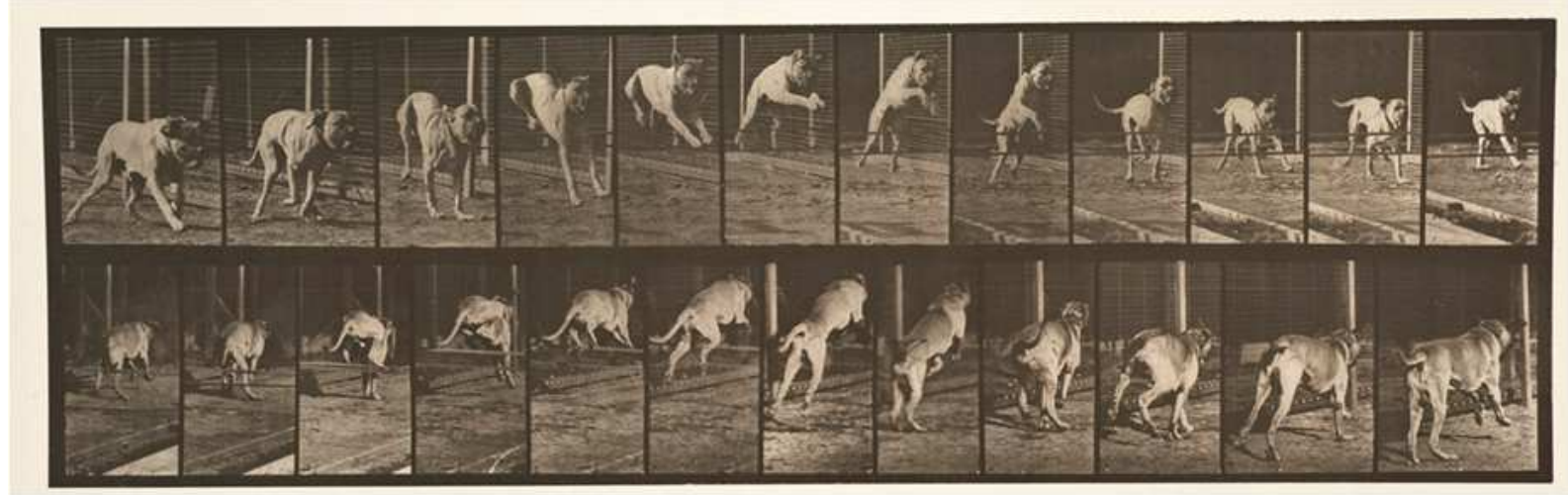

CuCo, Cuadernos de cómic número 1. Septiembre de 2013

CuCoEstudio 
FIG. 14. MuYBrIDGE, E. Animal Locomotion. Philadelphia, University of Pennsylvania Archives \& Record Center, 1887.

McCay diseñó asimismo una técnica para reproducir el movimiento lateral del punto de vista que caracteriza a secuencias como la del caballo de Muybridge. Se trata de una técnica muy usada en el cómic hoy día y a la que Gubern denominó raccord espacial, que consiste en segmentar un espacio continuo en varias viñetas mientras los personajes avanzan lateralmente atravesando los márgenes de las mismas, ${ }^{23}$ produciendo en el lector un efecto similar al que se produce en el cine cuando la cámara gira sobre su propio eje siguiendo a los personajes, es decir, una panorámica. McCay reservó este recurso para desplazamientos más lentos, no tan vertiginosos como los producidos por medios de transporte mecánicos como el coche o el tren, permitiéndole seguir la acción del relato al mismo tiempo que mostraba el escenario en toda su extensión (FIG. 16). En ocasiones, McCay utilizaba también el raccord espacial para seguir el desplazamiento de medios de transporte más lentos, como el globo o el dirigible (página del 13 de noviembre de 1910), pero siempre con intencionalidad retórica: en este caso, transmitir al lector la sensación que tienen los pasajeros de un globo de estar quietos mientras el mundo se mueve alrededor.

${ }^{23}$ Gubern, R. y GASCA, L. El discurso del cómic. Madrid, Cátedra, 1990, p. 630. 


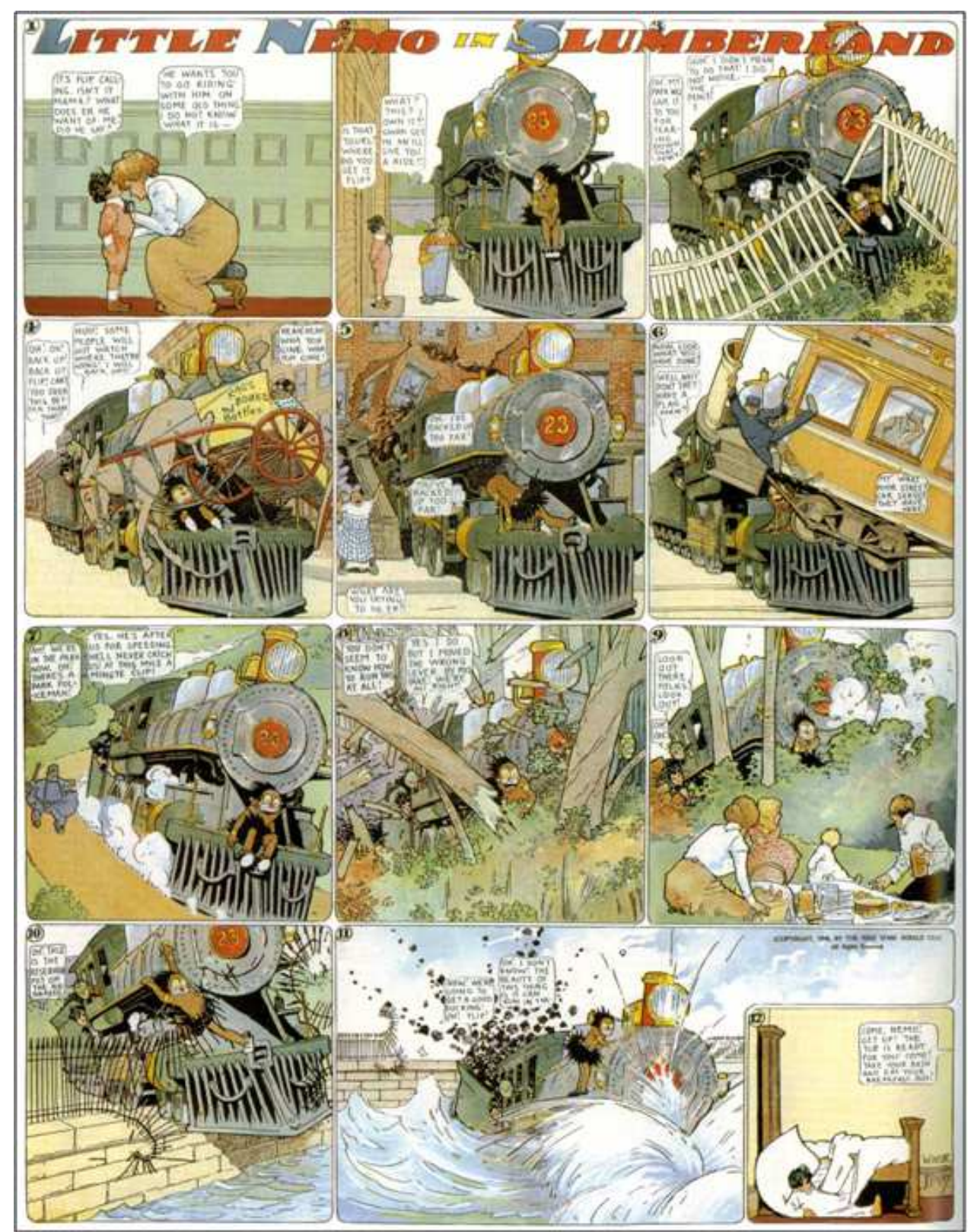

FIG. 15. MCCAY, W. Little Nemo, en The New York Herald, 3/1/1909. 


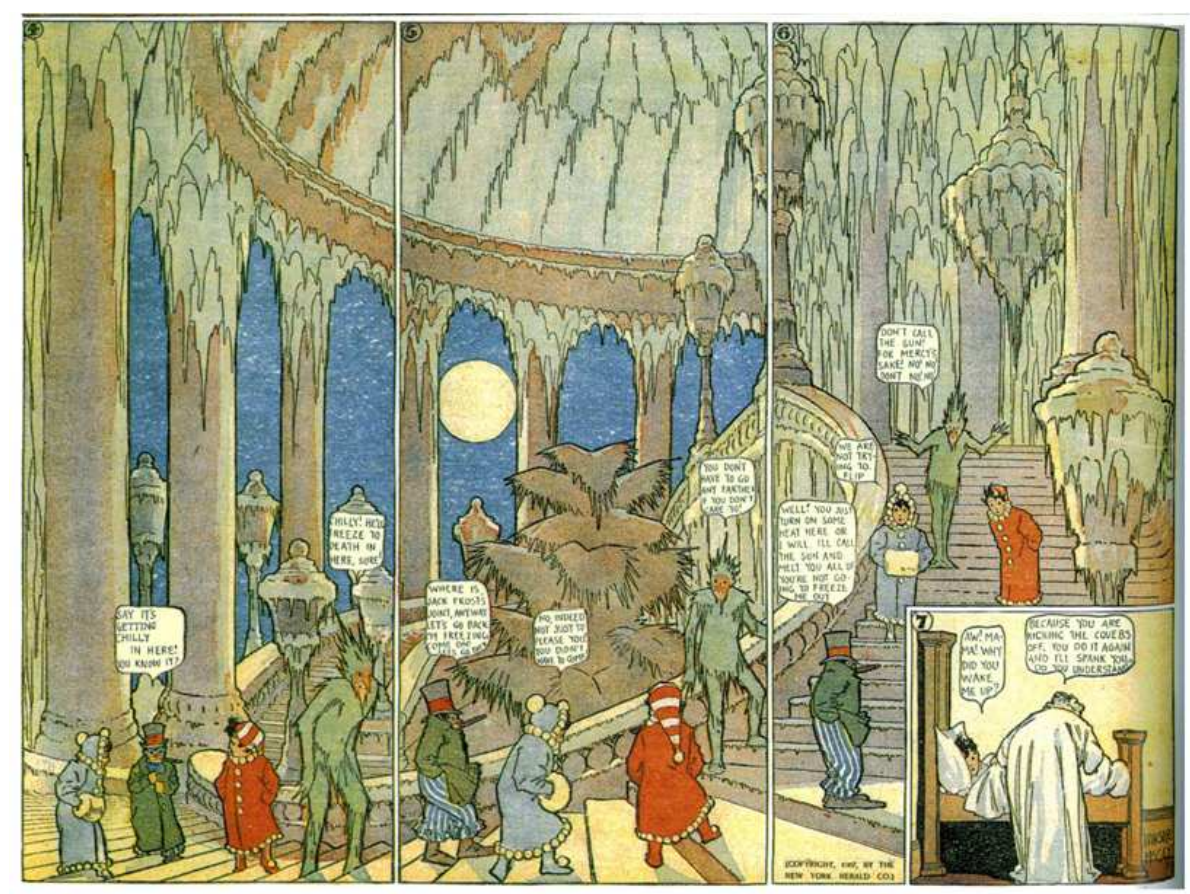

FIG. 16. MCCAY, W. Little Nemo, in The New York Herald, 27/1/1907.

\section{Conclusiones}

Antes de que pioneros como Pastrone, Griffith y Murnau dieran al travelling y la panorámica similares propósitos retóricos durante las décadas de 1910 y 1920, McCay ya se los había dado en el cómic. ${ }^{24} \mathrm{Y}$ aunque ya antes otros directores habían incorporado estos movimientos de cámara en sus películas, como por ejemplo Rescued by Rover (1905), de Cecil Hepworth, ${ }^{25}$ no fue hasta la aparición de Cabiria cuando se les empieza a dar un sentido propiamente narrativo. El hecho de que ambos medios compartan el antecedente de la cronofotografía, hace que cine y cómic vayan descubriendo casi simultáneamente las posibilidades de movimiento que les ofrece el

\footnotetext{
24 David Bordwell da el nombre de "travelling motivado" al travelling con intencionalidad retórica y atribuye a Griffith y a Murnau la popularización de su uso. BordwEll, D. On film style. Cambridge, Massachussets, Harvard University Press, 1997, p. 101.

${ }^{25}$ MoIX, T. Op. cit., p. 75.
} 
encuadre fotográfico. Sin embargo, estas posibilidades se consolidan como recursos estables de su sistema de significación antes en el cómic que en el cine, debido al elevado experimentalismo de los primeros cómics en la prensa estadounidense.

Atendiendo a la investigación de Kunzle, la narración gráfica en el medio impreso es un fenómeno tan antiguo como lo son el grabado y el libro. Sin embargo, la forma de narrar una historia con imágenes no siempre ha sido la misma. Desde la invención de la imprenta hasta principios del siglo XVIII, las viñetas funcionaban como estampas individuales cuya comprensión dependía totalmente del texto que las acompañaba. En el siglo XVIII, gracias al mayor detalle que le ofrece la técnica del aguafuerte, William Hogarth desarrolla un sistema de signos gráficos que le permite dar coherencia a la secuencia de imágenes y que cada una de estas se pueda expresar por sí misma, sin necesidad de texto. ${ }^{26} \mathrm{Al}$ introducir el libro como soporte de sus historietas, Rodolphe Töpffer acaba con las limitaciones de espacio haciendo posible la segmentación de las escenas y el desarrollo de estas a lo largo de un número variable de viñetas. Poco después de que el peculiar modo narrativo de Töpffer se extendiera incluso a otros soportes más condicionados por los límites de espacio, como por ejemplo, las revistas satíricas, aparece la cronofotografía, dotando a la narración gráfica de la posibilidad de representar secuencialmente el movimiento e incrementando considerablemente sus recursos dramáticos. Los primeros cómics de Reinicke, Öberlander, Steinlein y McCay ya no se contentan con narrar los cambios que se producen en el mundo y en sus personajes, sino que además los muestran imagen por imagen, partiendo de la observación detallada de la realidad.

El cambio tecnológico, y sobre todo el uso del libro y la invención de la cronofotografía, es el motor de la evolución formal de la narración gráfica, produciendo la aparición de nuevos recursos que, según se van consolidando e incorporando al sistema de significación del medio, acaban por transformarlo cualitativamente. Por esa

26 BARtuAL, R. "William Hogarth's A Harlot's Progress: the beginnings of a purely pictographic sequential language", en Studies in Comics, vol. 1, n. 1 (2010), pp. 83-105.

CuCo, Cuadernos de cómic número 1. Septiembre de 2013 
razón propongo reservar el uso del término "cómic" para referirnos a esta última encarnación de las narraciones gráficas que se define por la representación secuencial del movimiento y por su tendencia a presentar los acontecimientos narrativos de forma dramatizada. De esta manera podremos evitar los inconvenientes que plantean definiciones en extremo formalistas como la de McCloud, al tiempo que nos permite situar el cómic en el preciso contexto tecnológico e histórico al que pertenece.

\section{Bibliografía}

BARTUAL, R. "William Hogarth's A Harlot's Progress: the beginnings of a purely pictographic sequential language", Studies in Comics, vol. 1, $\mathrm{n}^{\mathrm{o}} 1$, Bristol, Intellect, 2010, pp. 83-105.

Bordwell, D. On film style. Cambridge, Massachussets, Harvard University Press, 1997.

Couch, N. C. C. "The Yellow Kid and the comics page", en VARnum, Robin Y GibBons, Christina T. (eds.). The Language of Comics: Word and Image, Jackson, University Press of Mississippi, 2001, pp. 60-74.

GARCíA, S. La novela gráfica. Madrid, Astiberri, 2010.

Gaudreault, A. y Jost, F. Le récit cinematographique: cinéma et recit II. París, Nathan. El relato cinematográfico. Trad. de PUJOL, L., Barcelona, Paidos, 1995.

Groensteen, T. y Peeters, B. Töpffer. L'invention de la bande dessinée. París, Hermann, 1994.

GuBERn, R. El lenguaje de los cómics. Barcelona, Península, 1972.

GuBERn, R. y GASCA, L. El discurso del cómic. Madrid, Cátedra, 1990.

CuCo, Cuadernos de cómic número 1. Septiembre de 2013

CuCoEstudio 
HARguindey, B. "As Cantigas de Santa María: obra mestra das orixes da historieta”, Boletín galego de literatura, $n^{\circ} 35$, Santiago de Compostela, Universidade de Santiago de Compostela, 2006, pp. 47-59.

HeER, J. "Comics and Photography: Research Note 1", Comics Comics Magazine, 4 de febrero, 2010, disponible on line en: http://comicscomicsmag.com/2010/02/comics-andphotography-research-note-1.html

KunZle, D. The History of the Comic Strip, vol. 1: The Early Comic Strip: Narrative Strips and Picture Stories in the European Broadsheet from c. 1450 to 1825. Berkeley, California, University of California Press, 1973.

—The History of the Comic Strip, vol. 2: The Nineteenth Century. Berkeley, California, University of California Press, 1990.

MoIX, T. La gran historia del cine. Vol. 1, Madrid, ABC, 1995.

MuYbridge, E. Animal Locomotion. Vols. 1-3, Mineola, Nueva York, Dover Publications, 1887 [1979].

RICKMAN, L. "Bande dessinée and the cinematograph: visual narrative in 1895", European Comic Art, vol. 1, n 1, Liverpool, Berghahn Journals, 2008, pp. 1-19.

SMOLDEREN, T. "Of Labels, loops and bubbles, solving the historical puzzle of the speech balloon", Comic Art, 8, Oakland, Buenaventura Press, 2006.

—Naissances de la bande dessinée. Bruselas, Les Impresions Nouvelles, 2009.

TöpfFer, R. "Essay de Physiognomonie", en Groensteen, T. y Peeters, B. (eds.). Töpffer. L'invention de la bande dessinée. París, Hermann, 1994, pp. 184-225.

Williams, A.L. Republic of images: a history of French filmmaking, Cambridge, Massachussets, Harvard University Press, 1992.

CuCo, Cuadernos de cómic número 1. Septiembre de 2013 